\title{
Uncovering the Role of Internal CSR on Organizational Attractiveness and Turnover Intention: The Effect of Procedural Justice and Extraversion
}

\author{
Sushant Ranjan ${ }^{1} \&$ Rama Shankar Yadav ${ }^{1}$ \\ ${ }^{1}$ Indian Institute of Management, Rohtak, India \\ Correspondence: Indian Institute of Management, Rohtak, India, Management City, Southern Bypass, NH 10, \\ Sunaria, Rohtak, Haryana 124001, India. Tel: 91-90-5073-1894. E-mail: fpm04.012@iimrohtak.ac.in (Sushant \\ Ranjan) \& rs.yadav@iimrohtak.ac.in (Rama Shankar Yadav).
}

Received: September 27, 2018

doi:10.5539/ass.v14n12p76
Accepted: October 5, $2018 \quad$ Online Published: November 29, 2018

URL: https://doi.org/10.5539/ass.v14n12p76

\begin{abstract}
The present study attempts to uncover the impact of internal CSR on internal stakeholders, i.e., employees. Through a comprehensive literature review, relevant variables for the study were identified such as internal CSR, the perception of procedural justice, organizational attentiveness, extraversion, and turnover intention. Drawing on signaling theory, we answer why employee's willingness to quit an organization is less if the organization performs well on internal CSR front. We also propose that internal CSR increases the organizational attractiveness as it reflects the prevalence of welfare practices and procedural justice in the organization. Since the organization is perceived procedurally just employee's willingness to quit the organization is decidedly less particularly employees having extrovert nature.
\end{abstract}

Keywords: extraversion personality, internal CSR, organizational attractiveness, perception of procedural justice, turnover intention

\section{Introduction}

Talented employees are competent, committed and also contribute to the organizational performance. However, their attraction and retention in the organization are very critical and is one of the biggest challenges, which the organization face in the present business scenario. According to a study conducted at McKinsey Global Institute by Dobbs, Madgavkar, Barton, \& Labaye (2012) reveals the challenges of attracting and retaining talent. The study also highlights the lack of highly skilled workers and its demand for the same across the globe by 2020 . At this critical juncture, it becomes essential to explore the determinants, which impact the attraction and retention of talents so that it may guide management practitioners.

Literature suggests that organizational attractiveness plays a pivotal role in attracting and retaining talented employees (Beechler \& Woodward, 2009). Further, organizational attractiveness depends on several factors such as corporate reputation and organizational identity (Bankins \& Waterhouse, 2018), perceived procedural justice and work-related expectancies (Lambert, Basuil, Bell, \& Marquardt, 2017), corporate social performance or CSR (Schmitz, 2017), diversity enhancement programs (Olsen, Parsons, Martins, \& Ivanaj, 2016) and diversity management (Ardakani, Abzari, Shaemi, \& Fathi, 2016).

There is a plethora of research, which emphasizes on the positive impact of CSR on business determinants such as trust, loyalty, financial performance, brand image (Maheshwari \& Yadav, 2015; Yadav, Jain, \& Singh, 2016). However, very less literature has emphasized the contribution of internal CSR on business determinants. In this study, we try to fill this void and investigate how internal CSR plays a vital role in organizational attractiveness and in turn impacts employee behavior such as turnover intention.

CSR is defined as the firm's concern and responsibility towards the issues which involves obligations and duty of an organization beyond the legal, economic and technical purpose of an organization (Davis, 1973). CSR activities are classified as external CSR and internal CSR (Story, Castanheira, \& Hartig, 2016). External CSR is the responsibilities of an organization towards the stakeholders present outside the boundary of an organization such as government, customer, local communities, business partner and society (Turker, 2009b). While internal CSR refers to trusts and obligation of the firms towards the internal operations of the firm (Brammer, Millington, 
\& Rayton, 2007). Turker (2009b) has defined internal CSR as responsibilities of a firm towards internal stakeholders, which involves the improvement of the working conditions of employees.

According to literature CSR influences behavior of employees in the form of organizational commitment (Turker, 2009a), organizational attractiveness (Story et al., 2016), organizational identification (Farooq, Rupp, \& Farooq, 2017), organizational trust (Tourigny, Han, Baba, \& Pan, 2017), organizational citizenship behavior (Newman, Schwarz, Cooper, \& Sendjaya, 2017). Further, internal CSR also impacts turnover intention of employees (Hawkar Rashid Arab, 2018; Low, Ong, \& Tan, 2017).

The underlying rationale why internal CSR positively impacts employees behavior is because it provides a sense of fairness and just to the processes and procedures in the internal operations of the firm. The perception of procedural justice helps the employees to get attracted towards an organization and in turn increasing his intention to stay within an organization, i.e., reducing his intention to quit the organization.

The appreciation and impact of CSR will be different for different people. The theoretical rationale lies in the stimuli-organism-response (S-O-R) framework developed by Woodworth (1947) and Mehrabian \& Russell (1974) who advocated that organisms respond to the same event or stimuli in different ways. Hence, we propose that extrovert people would perceive the impact of CSR on organizational attractiveness more strongly since they are highly social and have an appreciation for the social cause. Bathini \& Vohra (2013) have also suggested that individual with an extrovert personality are socially active and are more involved in volunteering and pro-social behavior such as CSR.

Turnover intention is a matter of concern for all organizations (Bhattacharya, Sen, \& Korschun, 2008). Turnover intention among employees reduces if there is an increase in work engagement (Liu \& Lo, 2017), safe workplace climate (Smith, 2017), quality of work life (Zhao et al., 2013) and justice at the workplace (Harris, Lavelle, \& McMahan, 2018). Since internal CSR by definition aims to provide justice and fairness in the work conditions, hence we proposed that turnover intention among employees will be lower if the organizations practice internal CSR.

A summary of our research propositions has been presented in the form of a conceptual framework, in the next section. The framework tries to explain the linkage between internal CSR activities and its impact on organizational attractiveness and turnover intention among employees. Further, extrovert personality traits and perception of procedural justice have been proposed as moderator and mediator respectively. In the subsequent sections, we have presented the literature review, conceptual framework, and proposition development and conclusion.

\section{Conceptual Framework}

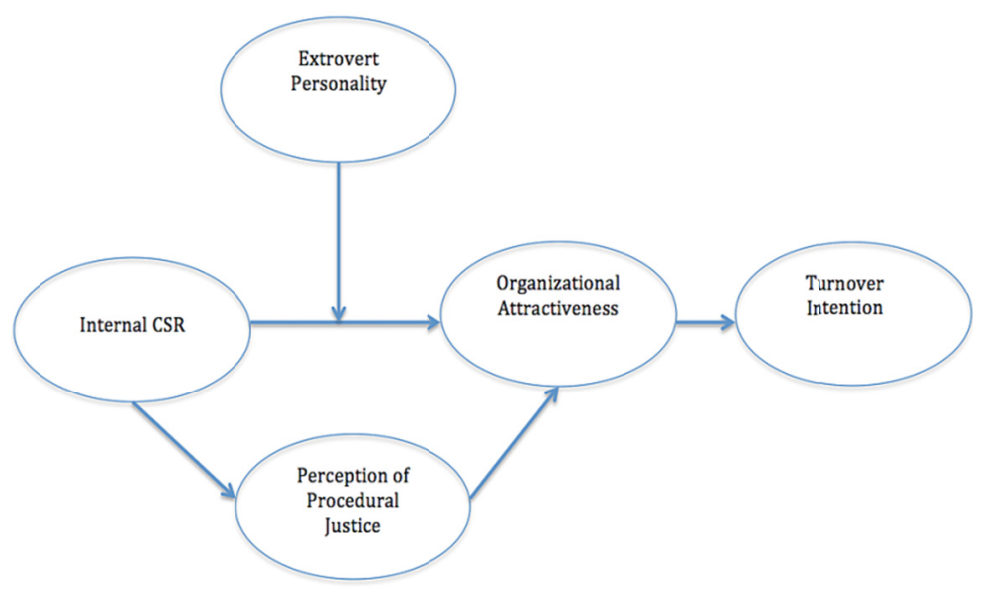

Figure 1. Conceptual framework showing the relationship between internal CSR, extrovert personality, procedural justice, organizational attractiveness, and turnover intention

\section{Literature Review and Proposition Development}

\subsection{Internal Corporate Social Responsibility (Internal CSR)}

Carroll (1979) had identified four components of CSR. These four components of CSR are ethical, legal, philanthropic and economic responsibilities of a firm. Economic responsibilities refer to the economic value creation of the firm, i.e., profit for shareholders. Legal responsibilities are obligations of the firm to follow the law of the land. Ethical responsibilities whereas dealing with a moral code of conduct of the firms. Lastly, 
discretionary responsibilities are concerned with philanthropic or charitable activities of the firm. Further, based on the kind of activities performed under the umbrella of CSR activities, Story et al. (2016) have classified CSR as internal CSR and external CSR types. In this study, we have focused broadly on the internal CSR types.

Internal CSR refers to the trusts and obligation of the firms towards internal stakeholders of the firm (Brammer et al., 2007). Hence, a firm's commitment to meet the expectations of employees, which is beyond the obligations of a firm, is internal CSR. While external CSR refers to the responsibilities of the firm towards external beneficiaries (Turker, 2009b).

Prior studies have found specific outcomes of CSR such as organizational commitment (Turker, 2009a), corporate reputation (Story et al., 2016), organizational identification (Farooq et al., 2017), organizational trust (Tourigny et al., 2017), supervisor ethical leadership (Gao \& He, 2017) and job performance (Newman et al., 2017). In the current study, we have presented organizational attractiveness as one of the outcomes of internal CSR. Past research has identified organizational attractiveness as one of the consequences of CSR (Ana Patrícia Duarte, Silva, Simões, \& Gonçalves, 2017; Reklitis, Trivellas, \& Mantzaris, 2018; Story et al., 2016), see Table1.

Table 1. Outcomes of CSR

\begin{tabular}{ll}
\hline Outcomes of CSR & Study \\
\hline Organizational commitment & (Turker, 2009a) \\
Corporate reputation & (Story et al., 2016) \\
Organizational attractiveness & (Story et al., 2016), (A.P. Duarte, Gomes, \& das Neves, 2014; \\
& Klimkiewicz \& Oltra, 2017) \\
Organizational identification & (Farooq et al., 2017) \\
Organizational trust & (Tourigny et al., 2017) \\
Supervisor ethical leadership & $($ Gao, 2017) \\
Organizational citizenship behavior, job performance & (Newman et al., 2017) \\
\hline
\end{tabular}

According to literature, internal CSR practices are related to skill development, career development opportunities of the employees, providing quality workplace, providing the balance between work and life, supporting employees in acquiring additional education, encouraging employees to participate in philanthropic and social activities. Since these internal practices are aimed to assist employees in their employability and better living conditions hence, these CSR practices are well appreciated by the employees and create a perception of procedural justice among them. The word of mouth publicity of the employees may be well received in the job market and hence, may help in attracting and retaining talent.

\subsection{Organizational Attractiveness}

Organizational attractiveness refers to the extent to which an individual will search for employment with a firm and would recommend other employees to join a particular organization (Lambert et al., 2017). Organizational attractiveness is defined as an inclination of an employee towards an organization for the reason of accepting an employment (Story et al., 2016).

The extant literature suggests that the organizational attractiveness is highly correlated with corporate reputation, organizational identity, and organizational image (Bankins \& Waterhouse, 2018), perceived work-related expectations (Lambert et al., 2017), corporate social performance (Schmitz, 2017), diversity management (Ardakani et al., 2016; Olsen et al., 2016)), corporate image (Held, 2016) see Table 2.

Table 2. Determinants of organizational attractiveness

\begin{tabular}{ll}
\hline Determinants of Organizational Attractiveness & Study \\
\hline Corporate reputation, organizational identity, organizational image & (Bankins \& Waterhouse, 2018) \\
Perceived work-related expectations & (Lambert et al., 2017) \\
Corporate social performance & (Schmitz, 2017) \\
Gender diversity programs, perceived potential for advancement & (Olsen et al., 2016) \\
Diversity management & (Ardakani et al., 2016) \\
Corporate character image & (Held, 2016) \\
\hline
\end{tabular}

Thus, based on the previous research it can be inferred that when an employee perceives an organization to be socially and procedurally fair then his/her willingness to accept a job offer from that particular firm is relatively high (Maheshwari \& Yadav, 2015). Drawing on signaling theory (Spence, 1973) we may infer that the internal 
CSR activities emit the positive signal about the work culture of the organization and hence, increase the attractiveness of the firm for prospective employees. Therefore, we propose that internal CSR is having the positive relationship with the organizational attractiveness.

Proposition 1: Internal CSR will positively impact the organizational attractiveness of an organization.

\subsection{Procedural Justice as a Mediator}

Leventhal (1980) has defined procedural justice as a level to which processes related to the decision-making at the workplace in an organization are sheer consistent, free of bias, correct and accurate. Greenberg \& Folger (1983) has referred procedural justice as consistency in the procedures and rules to allocate the resources at the workplace. Hence, procedural justice focuses on the just of the means employed to arrive at organizational outcomes (Greenberg, 1990).

The extant literature suggests that ethical leadership, group moral climate (Walumbwa, Hartnell, \& Misati, 2017), perceived CSR (Sarfraz, Qun, Abdullah, \& Alvi, 2018), and performance evaluation (Ridwan, Razak, \& Ismail, 2018) as some of the antecedents leading to the perception of procedural justice in the employees, see Table 3 .

Table 3. Predictors of Perception of Procedural Justice

\begin{tabular}{ll}
\hline Predictors of Perception of Procedural Justice & Study \\
\hline Gender, mental health, ethical leadership & (Somers \& Holtfreter, 2017) \\
Group moral climate & (Walumbwa et al., 2017) \\
Anger, satisfaction & (Yuning Wu et al., 2017) \\
Employees satisfaction & (Chan \& Lai, 2017) \\
Information sharing & (Tremblay \& Landreville, 2015) \\
Downsizing & Hart (2017) \\
\hline
\end{tabular}

Prior studies have also presented certain outcomes of procedural justice such as job performance (Hawkar Rashid Arab, 2018), innovative work behavior, employee engagement (W. Kim \& Park, 2017), compliance with the policies and moral (Yuning Wu, Sun, Chang, \& Hsu, 2017), perceived corporate support (Tremblay \& Landreville, 2015), increase in team performance (Colquitt, Noe, \& Jackson, 2002), pro-social behavior (Dijke, M. H., G., \& D., 2018), intent to stay (Mehmood, Nadarajah, Akhtar, Brohi, \& Khuhro, 2018), work engagement (Lamprakis, Alamani, Malliari, \& Grivas, 2018), organizational citizenship behavior (Sarfraz et al., 2018), organization identification (Bergami \& Gabriele, 2018) and perceived organization support (Lipponen, Steffens, \& Holtz, 2018), see Table 4.

Table 4. Outcomes of Perception of Procedural Justice

\begin{tabular}{ll}
\hline Outcomes of Perception of Procedural Justice & Study \\
\hline Employee computer abuse & (Willison, Warkentin, \& Johnston, 2016) \\
Job performance & (Hawker Rashid Arab, 2018) \\
Job satisfaction & (Yuning Wu et al., 2017), (Hawkar Rashid Arab, 2018) \\
$\begin{array}{l}\text { Employee work engagement, innovative work behavior, } \\
\text { sharing of knowledge }\end{array}$ & (W. Kim \& Park, 2017) \\
$\begin{array}{l}\text { Group learning behavior } \\
\text { Compliance with the policy, frustration, moral values, anger } \\
\text { Organizational citizenship behavior }\end{array}$ & (Walumbwa et al., 2017) \\
Perceived corporate support & (Yuning Wu et al., 2017) \\
\hline
\end{tabular}

In the current study, we have presented the internal aspect of CSR, which includes the safety of workers and improving the quality of work and wellbeing of an employee. De Roeck, Marique, Stinglhamber, \& Swaen (2014) and Aharon, Lior, Yaki, \& Gal (2011) has found support for internal CSR and justice to be strongly related in the workplace. The underlying assumption can be that the discretionary employee welfare activities induce the presence of procedural justice at the workplace.

The present study asserts that the signal emitted by the employee welfare activities, i.e., internal CSR are evaluated positively by prospective employees and hence enhance the organizational attractiveness of the firm. Therefore, we propose the following.

Proposition 2: Internal CSR will have a positive relationship with the perception of procedural justice. 
Proposition 3: Perception of procedural justice will have a positive relationship with organizational attractiveness.

\subsection{Turnover Intention}

Tett \& Meyer (1993) have referred the term turnover intention to ruminating of leaving an organization. Turnover intention also involves knowingly and purposively willing to quit a job in an organization (Egan, Yang, \& Bartlett, 2004). The turnover intention has been associated with several antecedents such as cynicism, high workload, emotional exhaustion, and low satisfaction (Liu \& Lo, 2017), organizational justice (Harris, Lavelle, \& McMahan, 2018), job stress (Labrague et al., 2018) organizational safety climate (Smith, 2017), work engagement (Liu \& Lo, 2017), affective commitments (Wong \& Wong, 2017) and work-family conflict (Lu et al., 2017), see Table 5.

Table 5. Predictors of Turnover Intention

\begin{tabular}{ll}
\hline Predictors of Turnover Intention & Study \\
\hline Cynicism, workload, emotional exhaustion & (Liu \& Lo, 2017) \\
Job satisfaction & (Labrague et al., 2018), (Prinn Sukriket, 2017), (Lee \& Chelladurai, \\
& 2017), (Liu \& Lo, 2017) \\
Job stress, age & (Labrague et al., 2018) \\
Safety climate & (Smith, 2017) \\
Work engagement & (Liu \& Lo, 2017) \\
Work-family conflict & (Lu et al.,2017) \\
Burnout & (Lee \& Chelladurai, 2017) \\
Affective commitments & (Wong \& Wong, 2017) \\
\hline
\end{tabular}

The present study extends the prior work on turnover intention by examining the influence of organizational attractiveness on turnover intention. The impact of organizational attractiveness over turnover intention has been rarely captured in earlier studies. Organizational attractiveness as discussed in the previous section is the extent to which an employee will search for employment within a firm and would recommend others employee to join that particular organization (Lambert et al., 2017). Since internal CSR activities emit a positive signal about the functioning of the firm thus, they may increase the attractiveness of the organization. Further, it is also expected that because of the presence of internal CSR intention to leave that particular organization will be low.

Proposition 4: Organizational attractiveness will have a negative relationship with turnover intention

\subsection{Moderating effect of Extrovert Personality}

Barrick \& Mount (1991) defined extraversion as a trait, which is dynamic, loquacious, confident, companionable and social. Extraversion has also been associated with social adaptability (Fiske, 1949), urgency (Tupes, 1961; Norman, 1963), assertiveness (Robbins, 1975), sociability (Hogan, 1986), and socially active (Guilford, 1975). Thus, extrovert individuals are highly social, compassionate, active, assertive and confident.

The extent literature suggested several outcomes of extraversion such as job performance (Barrick \& Mount,1991), job satisfaction (Harari, Thompson, \& Viswesvaran, 2018), emotional expression and self-esteem (Yanxia Wu, Lu, Chen, \& Bihua, 2018) and proactive behavior (Wang, Ang, Jiang, \& Wu, 2018), social support (McHugh Power, Lawlor, \& Kee, 2017), mastery, vigor and social cheerfulness (Fadda \& Scalas, 2016), job performance and organizational citizenship behavior (Gorman, 2014), see Table 6.

Table 6. Outcomes of Extrovert Personality

\begin{tabular}{ll}
\hline Consequences of Extrovert Personality & Study \\
\hline Job performance & (Bauer et al., 2006), (Barrick \& Mount, 1991) \\
Satisfaction & (Fadda \& Scalas, 2016), (Harari et al., 2018) \\
Emotional expression, proactive behavior & (Wang et al., 2018) \\
Self-esteem & (Fadda \& Scalas, 2016),(Wang et al., 2018) \\
Social support & (McHugh Power et al., 2017) \\
Mastery, vigor and social cheerfulness & (Fadda \& Scalas, 2016) \\
Job performance, organizational citizenship behavior & (Gorman, 2014) \\
Turnover Intention & (Bauer et al., 2006) \\
\hline
\end{tabular}


Prior literature has also found extraversion as a moderator to strengthen the bond between socio-informational behaviors and openness on social media (Saef, Woo, Carpenter, \& Tay, 2018), between leader-member exchange and job performance, turnover intention and actual intention of turnover (Bauer et al., 2006).

In the present study, we have conceptualized the moderating effects of extraversion on internal CSR and organizational attractiveness. Bathini \& Vohra (2013) validated that extrovert employees are more likely to be involved in volunteering activities and show pro-social behavior in organizations as they appreciate these activities. Since internal CSR is also pro-social and responsible acts of an organization towards its employees hence; we propose that extrovert employees will have the high appreciation for these activities as compared to employees who are low on this trait. Accordingly, we propose the following proposition.

Proposition 5: Extrovert personality trait moderates the relationship between internal CSR and organizational attractiveness such that organizational attractiveness is likely to be higher (lower) when extrovert personality trait is higher (lower) in employees.

\section{Discussion \& Conclusion}

The present study contributes to the existing literature by expanding the scope of research on CSR in talent management. This article in details focuses on the relationship between internal CSR and organizational attractiveness. Further, the moderating effect of extraversion between this relationship and the mediating effect of procedural justice is also studied. Based on an extensive literature review and the developed propositions authors conclude that internal CSR could be a useful tool for an organization to attract and retain employees within an organization. Further, the employees with high extrovert personality traits will be more inclined towards organizations, which are doing internal CSR and will have less intent to leave that organization.

The review also revealed that procedural justice at the workplace would influence the relationship between internal CSR and organizational attractiveness. Authors have further argued that internal CSR activities create the presence of procedural justice in the organization and in turn will influence the organizational attractiveness ultimately resulting in the lower turnover intention of employees. Authors suggest that the firm should concentrate on practicing internal CSR so that a positive signal is continuously emitted to the employees and prospective employees about the welfare work of the firm. The present study has future research implications. Authors recommend the empirical testing of propositions in various cultural contexts.

\section{References}

Aharon, T., Lior, O., Yaki, B., \& Gal, K. (2011). Corporate Social Responsibility, Organizational Justice and Job Satisfaction: How do They Interrelate, If at All? Revista de Psicología Del Trabajo y de Las Organizaciones, 27(1), 67-72. https://doi.org/10.5093/tr2011v27n1a7

Ardakani, M. S., Abzari, M., Shaemi, A., \& Fathi, S. (2016). Diversity management and human resources productivity : Mediating effects of perceived organizational attractiveness, organizational justice and social identity in Isfahan's steel industry. 9(2), 407-432.

Bankins, S., \& Waterhouse, J. (2018). Organizational Identity, Image, and Reputation: Examining the Influence on Perceptions of Employer Attractiveness in Public Sector Organizations. International Journal of Public Administration, 1-12. https://doi.org/10.1080/01900692.2018.1423572

Barrick, M. R., \& Mount, M. K. (1991). The Big Five Personality Dimensions and Job Performance: A Meta Analysis. Personnel Psychology, 44(1), 1-26. https://doi.org/10.1111/j.1744-6570.1991.tb00688.x

Bathini, D. R., \& Vohra, N. (2013). The role of traits, values and self-efficacy beliefs in volunteering. Indian Institute of Management, Ahmedabad, 1-34.

Bauer, T. N., Erdogan, B., Liden, R. C., \& Wayne, S. J. (2006). A longitudinal study of the moderating role of extraversion: Leader-member exchange, performance, and turnover during new executive development. Journal of Applied Psychology, 91(2), 298-310. https://doi.org/10.1037/0021-9010.91.2.298

Beechler, S., \& Woodward, I. C. (2009). The global "war for talent." Journal of International Management, 15(3), 273-285. https://doi.org/10.1016/j.intman.2009.01.002

Bergami, M., \& Gabriele, M. (2018). Relationship between perceived justice and identification: The mediating role of organizational images. Employee Relations, 7(1), 63-83. https://doi.org/10.1108/MRR-09-2015-0216

Bhattacharya, C. B., Sen, S., \& Korschun, D. (2008). Responsibility to Win the War for Talent Using Corporate Social Responsibility to Win the War for Talent, (49215).

Brammer, S. J., Millington, A., \& Rayton, B. A. (2007). The contribution of corporate social responsibility to 
organizational commitment. The International Journal of Human Resource Management, 18(10), 1701-1719. https://doi.org/10.1080/09585190701570866

Carroll, A. B. (1979). Three-Dimensional Conceptual Model of Corporate Performance, 4(4), 497-505.

Chan, S. H. J., \& Lai, H. Y. I. (2017). Understanding the link between communication satisfaction, perceived justice and organizational citizenship behavior. Journal of Business Research, 70, 214-223. https://doi.org/10.1016/j.jbusres.2016.08.017

Colquitt, J. A., Noe, R. A., \& Jackson, C. L. (2002). Justice in teams: Antecedents and consequences of procedural justice climate. Personnel Psychology, 55, 83-109.

Davis, K. (1973). The Case for and Against Business Assumption of Social Responsibilities. Academy of Management Journal, 16(2), 312-322. https://doi.org/10.2307/255331

de Roeck, K., Marique, G., Stinglhamber, F., \& Swaen, V. (2014). Understanding employees' responses to corporate social responsibility: Mediating roles of overall justice and organisational identification. International Journal of Human Resource Management, 25(1), 91-112. https://doi.org/10.1080/09585192.2013.781528

Dijke, V., M. H., L., G., D. C., \& D., \& A. (2018). Power, Procedural Justice, and Prosocial Behavior 1 Ranking Low, Feeling High: How Hierarchical Position and Experienced Power Promote Prosocial Behavior in Response to Procedural Justice. Journal of Applied Microbiology, 103(6), 10-12. https://doi.org/10.1111/j.1365-2672.2007.03484.x

Dobbs, R., Madgavkar, A., Barton, D., \& Labaye, E. (2012). The World at Work: Jobs, Pay and Skills for 3.5 Billion People. McKinsey Global Institute, (June), 1-108. Retrieved from https://members.aesc.org/eweb/upload/McKinsey Trend Break AESC.pdf

Duarte, A. P., Gomes, D. R., \& das Neves, J. G. (2014). Tell me your socially responsible practices, I will tell you how attractive for recruitment you are! The impact of perceived CSR on organizational attractiveness. Tékhne, 12(2014), 22-29. https://doi.org/10.1016/j.tekhne.2015.01.004

Duarte, A. P., Silva, V. H., Simões, E., \& Gonçalves, J. (2017). More socially responsible, more ethical, more attractive as a future employer? Contributes of corporate social performance and ethical reputation for the attraction of future employees, 31(2), 192-197.

Egan, T., Yang, B., \& Bartlett, K. (2004). The effects of organizational learning culture and job satisfaction on motivation to transfer learning and turnover intention. Human Resource Development Quarterly, 15(3), 279-301. https://doi.org/10.1002/hrdq.1104

Fadda, D., \& Scalas, L. F. (2016). Neuroticism as a moderator of direct and mediated relationships between introversion-extraversion and well-being. Europe's Journal of Psychology, 12(1), 49-67. https://doi.org/10.5964/ejop.v12i1.985

Farooq, O., Rupp, D. E., \& Farooq, M. (2017). The multiple pathways through which internal and external corporate social responsibility influence organizational identification and multifoci outcomes: The moderating role of cultural and social orientations. Academy of Management Journal, 60(3), 954-985. https://doi.org/10.5465/amj.2014.0849

Gao, Y., \& He, W. (2017). Corporate social responsibility and employee organizational citizenship behavior: The pivotal roles of ethical leadership and organizational justice. https://doi.org/http://dx.doi.org/10.1108/MRR-09-2015-0216

Gorman, C. A. (2014). The ambivert advantage: Curvilinear effects of extraversion on job performance and organizational citizenship behaviour. East Tennessee State University. Retrieved from http://www.utc.edu/psychology/pdfs/i-o/acgormanambivertadvantagercio2014.pdf

Greenberg, J., \& Folger, R. (1983). Procedural justice, participation, and the fair proces effect in groups and organizaitons. Basic Group Processes, (1975), 235-256.

Guilford, J. P. (1975). Factors and factors of personality. Psychological Bulletin, 82(5), 802-814. https://doi.org/10.1037/h0077101

Harari, M. B., Thompson, A. H., \& Viswesvaran, C. (2018). Extraversion and job satisfaction: The role of trait bandwidth and the moderating effect of status goal attainment. Personality and Individual Differences, 123(January), 14-16. https://doi.org/10.1016/j.paid.2017.10.041 
Harris, C. M., Lavelle, J. J., \& McMahan, G. C. (2018). The effects of internal and external sources of justice on employee turnover intention and organizational citizenship behavior toward clients and workgroup members. The International Journal of Human Resource Management, 5192, 1-24. https://doi.org/10.1080/09585192.2018.1441163

Hawkar Rashid Arab, T. A. (2018). Article information: Organizational justice and work outcomes in the Kurdistan Region of Iraq Hawkar. https://doi.org/10.1108/JEIM-07-2014-0077

Kim, S. Y., \& Park, H. (2011). Corporate Social Responsibility as an Organizational Attractiveness for Prospective Public Relations Practitioners. Journal of Business Ethics, 103(4), 639-653. https://doi.org/10.1007/s10551-011-0886-x

Kim, W., \& Park, J. (2017). Examining structural relationships between work engagement, organizational procedural justice, knowledge sharing, and innovative work behavior for sustainable organizations. Sustainability (Switzerland), 9(2). https://doi.org/10.3390/su9020205

Klimkiewicz, K., \& Oltra, V. (2017). Does CSR Enhance Employer Attractiveness? The Role of Millennial Job Seekers' Attitudes. Corporate Social Responsibility and Environmental Management, 24(5), 449-463. https://doi.org/10.1002/csr.1419

Labrague, L. J., Gloe, D. S., McEnroe-Petitte, D. M., Tsaras, K., \& Colet, P. C. (2018). Factors influencing turnover intention among registered nurses in Samar Philippines. Applied Nursing Research, 39(November 2017), 200-206. https://doi.org/10.1016/j.apnr.2017.11.027

Lambert, J. R., Basuil, D. A., Bell, M. P., \& Marquardt, D. J. (2017). Coming to America: work visas, international diversity, and organizational attractiveness among highly skilled Asian immigrants. International Journal of Human Resource Management, 5192, 1-27. https://doi.org/10.1080/09585192.2017.1322116

Lamprakis, A., Alamani, K., Malliari, A., \& Grivas, I. (2018). The organisational justice as a human resources management practice and its impact on employee engagement: The case of the prefecture of Attica (Greece). Scientific Annals of Economics and Business, 65(1), 65-79. https://doi.org/10.2478/saeb-2018-0004

Lee, Y. H., \& Chelladurai, P. (2017). Emotional intelligence, emotional labor, coach burnout, job satisfaction, and turnover intention in sport leadership. European Sport Management Quarterly, 0(0), 1-20. https://doi.org/10.1080/16184742.2017.1406971

Leventhal, G. (1980). What Should Be Done with Equity Theory? Social Exchanges: Advances in Theory and Research, 27-55.

Lipponen, J., Steffens, N. K., \& Holtz, B. C. (2018). Prototypical supervisors shape lay-off victims' experiences of top management justice and organizational support. Journal of Occupational and Organizational Psychology, 91(1), 158-180. https://doi.org/10.1111/joop.12197

Liu, H. L., \& Lo, V. hwei. (2017). An integrated model of workload, autonomy, burnout, job satisfaction, and turnover intention among Taiwanese reporters. Asian Journal of Communication, 0(0), 1-17. https://doi.org/10.1080/01292986.2017.1382544

Low, M. P., Ong, S. F., \& Tan, P. M. (2017). Would Internal Corporate Social Responsibility Make a Difference in Professional Service Industry Employees' Turnover Intention? A Two-Stage Approach Using PLS-SEM. Global Business and Management Research, 9(1), 24-41. Retrieved from https://search.proquest.com/docview/1882017163?accountid=133056

Lu, Y., Hu, X.-M., Huang, X.-L., Zhuang, X.-D., Guo, P., Feng, L.-F., ... Hao, Y.-T. (2017). The relationship between job satisfaction, work stress, work-family conflict, and turnover intention among physicians in Guangdong, China: a cross-sectional study. BMJ Open, 7(5), e014894. https://doi.org/10.1136/bmjopen-2016-014894

Maheshwari, S., \& Yadav, S. (2015). Is CSR a Hygiene Factor for Prospective Employees? An Indian Exploration. 50(4), 601-613.

McHugh Power, J. E., Lawlor, B. A., \& Kee, F. (2017). Social support mediates the relationships between extraversion, neuroticism, and cognitive function in older adults. Public Health, 147, 144-152. https://doi.org/10.1016/j.puhe.2017.02.015

Mehmood, S. A., Nadarajah, D., Akhtar, M. S., Brohi, N. A., \& Khuhro, M. A. (2018). A conceptual framework explaining the impact of perceived career growth and organizational justice on intention to stay among city 
traffic police Lahore. International Journal of Engineering and Technology (UAE), 7(2). https://doi.org/10.14419/ijet.v7i2.33.13903

Mehrabian, A., \& Russell, J. A. (1974). An approach to environmental psychology. An approach to environmental psychology. Cambridge, MA, US: The MIT Press.

Newman, A., Schwarz, G., Cooper, B., \& Sendjaya, S. (2017). How Servant Leadership Influences Organizational Citizenship Behavior: The Roles of LMX, Empowerment, and Proactive Personality. Journal of Business Ethics, 145(1), 49-62. https://doi.org/10.1007/s10551-015-2827-6

Olsen, J. E., Parsons, C. K., Martins, L. L., \& Ivanaj, V. (2016). Gender diversity programs, perceived potential for advancement, and organizational attractiveness: An empirical examination of women in the United States and France. Group and Organization Management, 41(3), 271-309. https://doi.org/10.1177/1059601115583579

Prinn Sukriket. (2017). The Relationship Between Job Satisfaction and Turnover Intention of Thai Software Programm ers In Bangkok, Thailand.

Reklitis, P., Trivellas, P., \& Mantzaris, I. (2018). Sustainability and Social Responsibility: Regulation and Reporting, 225-240. https://doi.org/10.1007/978-981-10-4502-8

Ridwan, M., Razak, A., \& Ismail, A. (2018). The Mediating Effects of Procedural Justice on the Relationship between Performance-based Remuneration Management and Job Satisfaction. Jurnal Pengurusan, 52, 52.

Robbins, B. (1975). The structure of personality. The American Journal of Psychoanalysis, 35(I), 175-176.

Saef, R., Woo, S. E., Carpenter, J., \& Tay, L. (2018). Fostering socio-informational behaviors online: The interactive effect of openness to experience and extraversion. Personality and Individual Differences, 122(May 2017), 93-98. https://doi.org/10.1016/j.paid.2017.10.009

Sarfraz, M., Qun, W., Abdullah, M. I., \& Alvi, A. T. (2018). Employees' perception of Corporate Social Responsibility impact on employee outcomes: Mediating role of organizational justice for Small and Medium Enterprises (SMEs). Sustainability (Switzerland), 10(7). https://doi.org/10.3390/su10072429

Smith, T. D. (2017). An assessment of safety climate, job satisfaction and turnover intention relationships using a national sample of workers from the USA. International Journal of Occupational Safety and Ergonomics, 3548(January 2017), 1-8. https://doi.org/10.1080/10803548.2016.1268446

Somers, L. J., \& Holtfreter, K. (2017). Gender and mental health: An examination of procedural justice in a specialized court context. Behavioral Sciences and the Law, (February). https://doi.org/10.1002/bsl.2325

Story, J., Castanheira, F., \& Hartig, S. (2016). Corporate social responsibility and organizational attractiveness: implications for talent management. Social Responsibility Journal, 12(3), 484-505. https://doi.org/10.1108/SRJ-07-2015-0095

Tett, R. P., \& Meyer, J. P. (1993). Job satisfaction, organizational commitment, turnover intention, and turnover: Path analyses based on meta-analytic findings. Personnel Psychology, 46(2), 259-293. https://doi.org/10.1111/j.1744-6570.1993.tb00874.x

Tourigny, L., Han, J., Baba, V. V., \& Pan, P. (2017). Ethical Leadership and Corporate Social Responsibility in China: A Multilevel Study of Their Effects on Trust and Organizational Citizenship Behavior. Journal of Business Ethics, (0123456789), 1-14. https://doi.org/10.1007/s10551-017-3745-6

Tremblay, M., \& Landreville, P.-E. (2015). Information Sharing and Citizenship Behaviors. International Journal of Business Communication, 52(4), 347-368. https://doi.org/10.1177/2329488414525459

Turker, D. (2009a). How Corporate Social Responsibility Influences Organizational Commitment. Source Journal of Business Ethics Journal of Business Ethics, 89(2), 189-204. https://doi.org/10.1007/s10551-008-9993-8

Turker, D. (2009b). Measuring corporate social responsibility: A scale development study. Journal of Business Ethics, 85(4), 411-427. https://doi.org/10.1007/s10551-008-9780-6

Vida Skudiene, V. A. (2012). Article information: The contribution of corporate social responsibility to internal employee motivation. http://dx.doi.org/10.1108/JEIM-07-2014-0077

Walumbwa, F. O., Hartnell, C. A., \& Misati, E. (2017). Does ethical leadership enhance group learning behavior? Examining the mediating influence of group ethical conduct, justice climate, and peer justice. Journal of Business Research, 72, 14-23. https://doi.org/10.1016/j.jbusres.2016.11.013 
Wang, Y., Ang, C., Jiang, Z., \& Wu, C. H. (2018). The role of trait extraversion in shaping proactive behavior: A multilevel examination of the impact of high-activated positive affect. Personality and Individual Differences, (February), 0-1. https://doi.org/10.1016/j.paid.2018.01.035

Willison, R., Warkentin, M., \& Johnston, A. C. (2016). Examining employee computer abuse intentions: Insights from justice, deterrence and neutralization perspectives. Information Systems Journal. https://doi.org/10.1111/isj.12129

Wong, Y.-W., \& Wong, Y. (2017). The effects of perceived organizational support and affective commitment on turnover intention. Journal of Chinese Human Resources Management, 8(1), 2-21. https://doi.org/10.1108/JCHRM-01-2017-0001

Woodworth, R. S. (1947). Reënforcement of Perception, 60(1), 119-124.

Wu, Y., Sun, I. Y., Chang, C. K. M., \& Hsu, K. K. L. (2017). Procedural Justice Received and Given: Supervisory Treatment, Emotional States, and Behavioral Compliance Among Taiwanese Police Officers. Criminal Justice and Behavior, 44(7), 963-982. https://doi.org/10.1177/0093854817702407

Wu, Y., Lu, J., Chen, N., \& Bihua, X. (2018). The Influence of Extraversion on Emotional Expression: A Moderated Mediation Model. Social Behavior and Personality, 46(4), 1-12.

Yadav, R. K., Jain, R., \& Singh, S. (2016). An overview of Corporate Social Responsibility ( CSR ) in insurance sector with special reference to Reliance Life Insurance, 45(2), 196-223.

Zhao, X., Sun, T., Cao, Q., Li, C., Duan, X., Fan, L., \& Liu, Y. (2013). The impact of quality of work life on job embeddedness and affective commitment and their co-effect on turnover intention of nurses. Journal of Clinical Nursing, 22(5-6), 780-788. https://doi.org/10.1111/j.1365-2702.2012.04198.x

\section{Copyrights}

Copyright for this article is retained by the author(s), with first publication rights granted to the journal.

This is an open-access article distributed under the terms and conditions of the Creative Commons Attribution license (http://creativecommons.org/licenses/by/4.0/). 